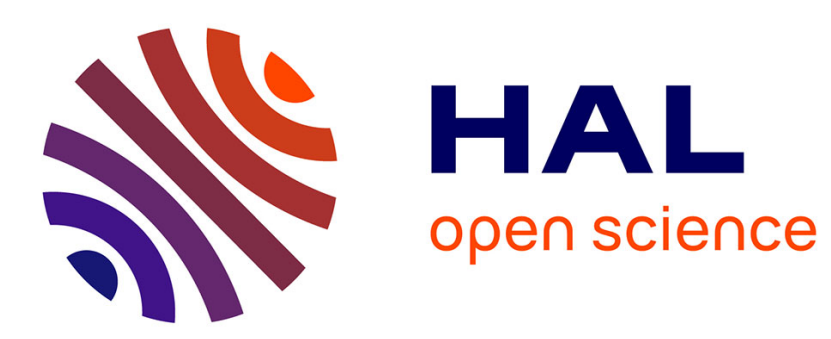

\title{
Cytostatic effect of polyethylene glycol on human colonic adenocarcinoma cells.
}

\author{
G. Parnaud, D. E. Corpet, Laurence Gamet-Payrastre
}

\section{To cite this version:}

G. Parnaud, D. E. Corpet, Laurence Gamet-Payrastre. Cytostatic effect of polyethylene glycol on human colonic adenocarcinoma cells.. International Journal of Cancer, 2001, 92 (1), pp.63-9. hal00325666

\section{HAL Id: hal-00325666 \\ https://hal.science/hal-00325666}

Submitted on 29 Sep 2008

HAL is a multi-disciplinary open access archive for the deposit and dissemination of scientific research documents, whether they are published or not. The documents may come from teaching and research institutions in France or abroad, or from public or private research centers.
L'archive ouverte pluridisciplinaire HAL, est destinée au dépôt et à la diffusion de documents scientifiques de niveau recherche, publiés ou non, émanant des établissements d'enseignement et de recherche français ou étrangers, des laboratoires publics ou privés. 


\title{
Cytostatic effect of polyethylene-glycol on human colonic adenocarcinoma cells
}

\author{
Géraldine PARNAUD ${ }^{1}$, Denis E. CORPET ${ }^{2}$ and Laurence PAYRASTRE ${ }^{1 *}$ \\ ${ }^{1}$ Laboratoire des Xénobiotiques, INRA, 180 Chemin de Tournefeuille, 31931 Toulouse, France \\ ${ }^{2}$ Laboratoire de Sécurité des Aliments, INRA, ENVT, 23 Ch. des Capelles, 31076 Toulouse, France
}

Polyethylene glycol (PEG 8000) is a potent cancer chemopreventive agent. This osmotic laxative polymer markedly suppresses colon cancer in rats. To explain the mechanism, we have tested the in vitro effect of PEG on four human cell lines. Two poorly differentiated adenocarcinoma lines (HT29 and COLO205), a fetal mucosa line (FHC) and a differentiated line (post-confluent Caco-2) were incubated with various PEG concentrations for 2-5 days. Results show that PEG markedly and dosedependently inhibited HT29 and COLO205 cell growth. This cytostatic effect was associated with a blocking of the cell cycle in G0/G1 phase. In addition, PEG decreased the viability of HT29 and COLO205 adenocarcinoma cells. In contrast, post-confluent intestinal-like Caco-2 cells and normal FHC cells were, respectively, not or little affected by PEG. Moreover, the lactate concentration increased twofold in the medium of PEGtreated HT29 cells compared with untreated cells. Microscopic observations showed that PEG induced cell shrinking, membrane blebbing and the condensation of nuclear chromatin. However, because no DNA ladder and no annexin staining were detected, we presume that PEG did not induce apoptosis. PEG increased the osmotic pressure of the culture medium. Hyperosmotic media with added NaCl or sorbitol also inhibited HT29 cell growth, and increased lactate release. These results suggest that PEG may be selectively cytostatic for proliferating cancer cells. This growth inhibition may be due to the high osmotic pressure induced by PEG in vitro. Because the osmotic pressure is high in feces of PEG-fed rats, it may explain the suppression of colon carcinogenesis by PEG.

\footnotetext{
* Correspondence to: Laboratoire des Xénobiotiques, INRA, 180 Chemin de Tournefeuille, 31931 Toulouse, France E-mail: lpayrast@toulouse.inra.fr, Tel: 33561285 383, Fax: 33561285244.
}

Colon cancer is a major cause of mortality in the Western world (Potter et al., 1993), and its prevention is urgently needed. Several natural products of vegetal origin could be of potential value as chemopreventive or therapeutic agents (Stavric, 1994). These chemopreventers include some vitamins, plant polyphenols, and some components in spices. Non-steroidal anti-inflammatory drugs also have preventive effect against colorectal cancer (Weiss and Forman, 1996). Moreover, we have demonstrated the potent chemopreventive property of a food additive agent, polyethyleneglycol, against rat colonic carcinogenesis (Corpet and Parnaud, 1999, Parnaud et al., 1999, Corpet et al., 2000).

Polyethylene-glycol 8000 (PEG) is a solid polymer of the general formula $\mathrm{H}\left(\mathrm{O}-\mathrm{CH}_{2-}\right.$ $\left.\mathrm{CH}_{2}\right)_{\mathrm{n}}-\mathrm{OH}$ where $\mathrm{n}=200$. PEG of high molecular weight, like PEG 8000, show little or no toxicity (LD50 in rats $>50 \mathrm{~g} / \mathrm{kg}$ ) (Windholz, 1983). These agents are on the Food and Drug Administration's GRAS (generally regarded as safe) list and are used as food additives. In France and in the USA their water holding capacity has led to their use as gentle laxatives at a dose of 10 to 20g/day (Attar et al., 1999).

PEG, given orally in food at a daily dose corresponding to $5 \%$ of the dry weight of the diet, markedly inhibits azoxymethane-induced colon carcinogenesis in F344 rats as assessed by aberrant crypt foci number and size (Corpet and Parnaud, 1999). PEG-fed rats had 20 times fewer aberrant crypt foci and 100 times fewer large aberrant crypt foci than controls. We have also found that the administration of 5\% PEG in drinking water causes a dose-dependent regression of aberrant crypt foci, and strongly suppresses colorectal cancers in rats (Parnaud et al., 1999). PEG suppresses carcinogenesis induced by various carcinogens, in both rats and mice, and its effect on preneoplastic lesions is very fast (Corpet et al., 2000). Until now, no 
work has been done to elucidate PEG's mechanism of action. Nevertheless, we have observed that dietary PEG halves the fecal concentration of bile acids and the fecal water toxicity (Corpet and Parnaud, 1999). However, the dilution of potential toxic components in the digestive tract may not be enough to explain the high protection afforded by PEG. Indeed, some dietary fibers like wheat bran and psyllium can double the fecal bulk while exerting only a small preventive effect on azoxymethane-induced aberrant crypt foci (Alabaster et al., 1993).

In this study, we investigated PEG effects on 4 human colonic cell lines, the human adenocarcinoma HT29 and COLO 205 cells, the human fetal mucosa FHC cells, and the postconfluent intestinal-like Caco-2 cells. Our results clearly show that PEG reduced, in a dosedependent manner, the proliferation rate of the 2 cancerous cells during their exponentially growing phase. Moreover, this polymer did not exert any significant toxic effect on postconfluent intestinal-like Caco-2 cells and only slightly decreased viability of FHC cells.

\section{MATERIALS AND METHODS \\ Drugs and chemicals \\ Dulbecco's modified Eagle's medium} (DMEM) and fetal calf serum (FCS) were purchased from Life Technologies (France). Annexin-V-fluorescein, NAD, and L Lactate deshydrogenase were obtained from Boeringher Mannheim (France). PEG 8000 was obtained from ICN (Orsay, France). RPMI 1640 medium, Ham's nutrient mixture (F12) and all other chemicals were purchased from Sigma (St Louis, MO) or from Merck (Darmstadt, Germany) and were of the highest purity available.

\section{Cell culture}

HT29 and Caco-2 cells were purchased from European Collection of Cell Culture (ECACC, Salisbury, UK), COLO 205 and FHC cells were purchased from American Type Culture Collection (Manassas, VA, USA). Routinely, HT29 and Caco-2 stock cells were cultured in DMEM containing $25 \mathrm{mM}$ glucose, $43 \mathrm{mM}$ bicarbonate, $60 \mu \mathrm{M} / \mathrm{ml}$ penicillin, 100 $\mu \mathrm{g} / \mathrm{ml}$ streptomycin at $37^{\circ} \mathrm{C}$, under an air $/ \mathrm{CO}_{2}$ (9/1) atmosphere supplemented with $5 \%$ or $10 \%$ heat-inactivated FCS respectively. Caco-2 cell medium was also supplemented with $1 \%$ non- essential amino acids. COLO 205 cells were cultured in RPMI 1640 medium with $2 \mathrm{mM} \mathrm{L-}$ glutamine adjusted to contain $1.5 \mathrm{~g} / \mathrm{l}$ sodium bicarbonate, $25 \mathrm{mM}$ glucose, $10 \mathrm{mM}$ HEPES and $1 \mathrm{mM}$ sodium pyruvate supplemented with $10 \%$ heat-inactivated FCS. FHC cells were grown by combining one part of DMEM and one part of Ham's nutrient mixture (F12), supplemented with 20\% FCS, 25 mM HEPES, $10 \mathrm{ng} / \mathrm{ml}$ cholera toxin, $5 \mu \mathrm{g} / \mathrm{ml}$ insulin, $5 \mu \mathrm{g} / \mathrm{ml}$ transferrin, and $100 \mathrm{ng} / \mathrm{ml}$ hydrocortisone. For all cell lines the medium was changed every 48 hours. For the non synchronized experiments, HT29 and COLO 205 cells were seeded at low density $\left(5 \times 10^{4}\right.$ cells per $\left.\mathrm{ml}\right)$ in 6 well-plates in standard medium containing $5 \%$ or $10 \%$ FCS respectively. One day after seeding, cells were treated with different doses of PEG. For the experiments on synchronized cells, HT29 cells were seeded at low density $\left(5 \times 10^{4}\right.$ cells per ml) in 6 well-plates in standard medium containing $5 \%$ FCS. One day after seeding cells were placed in serum-free medium for 20 hours in order to arrest cell growth, then HT29 cells were treated with different doses of PEG (from 3.2 to $20 \mathrm{mM}$ ) in 5\% FCS-containing medium. In assays requiring confluent conditions, FHC, Caco-2 and HT29 cells were plated at $5 \times 10^{4}$ cells per ml and allowed to grow to confluence. Then HT29 cells were treated at confluence with PEG in a range of concentration from 3.2 to $15 \mathrm{mM}$. Caco-2 cells were treated 2 weeks after they had reached confluence. At this time, they spontaneously exhibit enterocyte-like differentiation (Fogh and Zweibaum, 1983). FHC cells were grown to subconfluence (80\%) before treatment with PEG $5 \mathrm{mM}$ or $10 \mathrm{mM}$ for 5 days.

\section{Estimation of growth rate}

Cell growth was measured by cell counting using a Coulter Counter (Beckman). At the indicated times, culture medium was removed and cells layers was rinsed with PBS. The cells were detached by treatment of the cell layers with $500 \mu \mathrm{l}$ of $0.25 \%$ trypsin- $0.6 \mathrm{mM}$ EDTA in PBS during $5 \mathrm{~min}$ at $37^{\circ} \mathrm{C}$. Trypsin action was stopped by addition of $1 \mathrm{ml}$ of $5 \%$ FCS-containing medium. A $100 \mu \mathrm{l}$ aliquot was diluted in $10 \mathrm{ml}$ of Isoton II diluent and then counted. Results are expressed as cell number per well. 


\section{Cell viability assay}

PEG effect on cellular viability was evaluated using an assay based on the cleavage of the yellow dye 3-(4,5-dimethyl-2-thiazolyl)2,5-diphenyl-2H-tetrazolium bromide (MTT) to purple formazan crystals by deshydrogenase activity in mitochondria, a conversion which occurs only in living cells (Husoy et al., 1993). At each time point, medium was removed and cell layers were rinsed with phenol red-free RPMI medium, then they received MTT diluted $(0.5 \mathrm{mg} / \mathrm{ml})$ in RPMI for 4 hours. The cells were then solubilized in $1 \%$ SDS in $\mathrm{NaOH} 0.1 \mathrm{~N}$ and the optical density of the cellular homogenate was measured at 570 and $690 \mathrm{~nm}$.

\section{Flow cytometry analysis}

Drug effect on cell proliferation was evaluated by measuring the distribution of the cells in the different phases of the cell cycle by flow cytometry. This determination was based on the measurement of the DNA content of nuclei labeled with propidium iodide according to the method of Vindelov and Christensen (1990) slightly modified. Cell suspensions from either untreated or treated cultures were prepared by trypsinization and washed twice with $0,9 \%$ $\mathrm{NaCl}$. Cells $\left(1 \times 10^{6}\right)$ were resuspended in $220 \mu \mathrm{l}$ of solution A (trisodium citrate $3.4 \mathrm{mM} \mathrm{pH} \mathrm{7.6;}$ Nonidet P40 0.1\%; spermine tetrahydrochloride $1.5 \mathrm{mM}$ and Trisbase $0.5 \mathrm{mM}$ ) containing trypsin (30 mg/L) for 10 minutes at room temperature. Trypsin was then inhibited by addition of $180 \mu \mathrm{l}$ of solution A containing trypsin inhibitor (0.5 $\mathrm{g} / \mathrm{L})$ and RNase A $(100 \mathrm{mg} / \mathrm{L})$ for an additional 10 minutes. Finally, nuclei were labeled by addition of $180 \mu \mathrm{l}$ of solution A containing propidium iodide (416 mg/L) and additional spermine tetrahydrochloride (1160 mg/L). The suspension was incubated overnight at $4^{\circ} \mathrm{C}$ to allow maximum labeling of DNA. Analysis of cell cycle was performed on a Coulter ELITE flow cytometer through a $630 \mathrm{~nm}$ LP filter. Debris and doublets were eliminated by gating on peak versus integrated signals and $1.5 \times 10^{4}$ cells were collected per sample. Calculations were performed with MULTICYCLE AV Software (Phoenix Flow System).

\section{Analysis of chromatin}

Cells were plated at low density $\left(1.25 \times 10^{5}\right.$ cells per well) on glass cover slides (Esco, 20x20 $\mathrm{mm}$, Erie Scientific, Porthmouth, NH, USA) in 6 well- plates and treated with PEG $5 \mathrm{mM}$ or $10 \mathrm{mM}$ for 48 hours. At the end of the experiment, cells were washed twice with phosphate buffered saline at room temperature, then fixed with ice-cold methanol/ethanol (v/v 1/1) for 10 minutes at -20 ${ }^{\circ} \mathrm{C}$. Fixed cells were rinsed with PBS and stained with Hoechst $33342(10 \mu \mathrm{g} / \mathrm{ml})$ in PBS (15 minutes at room temperature in the dark). Finally, cells were washed 3 times with PBS and analyzed under a fluorescence microscope with an UV light filter.

\section{Lactate release}

To measure lactate release, the medium was collected $48 \mathrm{~h}$ after the beginning of the experiment and deproteinized with $0.6 \mathrm{M}$ perchloric acid (v/v 1/2). L-lactate concentration was measured in a $100 \mu$ l aliquot of the deproteinized supernatant using lactate dehydrogenase and NAD according to Hohorst and Bergmeyer (1974). The change in optical density was read at $340 \mathrm{~nm}$. Results are expressed as $\mu$ mole/mg of total cellular protein or per $10^{6}$ cells.

\section{Total protein content and osmotic pressure} determination

Total protein content was determined using the method of Bradford (1976). Cells layers were lysed by addition of $1 \mathrm{ml}$ of $\mathrm{NaOH}$ $0.1 \mathrm{~N}$. One aliquot of cell lysate was then stained with Coomassie Blue and optical density was read at $595 \mathrm{~nm}$. Protein concentrations were calculated using BSA as standard.

Osmotic pressures of culture media were determined by freezing point depression with an osmometer (OSMOMAT 030, Gonotec, Berlin, Germany).

\section{RESULTS}

Antiproliferative effect of PEG

We first investigated the effect of PEG on nonsynchronized HT29 and COLO 205 colonic adenocarcinoma cells, during their exponentially growing phase. Cells were incubated or not (untreated cells) with increasing concentrations of PEG in complete culture medium for 1,2 and 5 days. Growth was estimated by cell counting at the indicated time. As shown in Fig.1, we observed, for both cancerous cells lines, an arrest of cell growth in treated compared to untreated cells. 


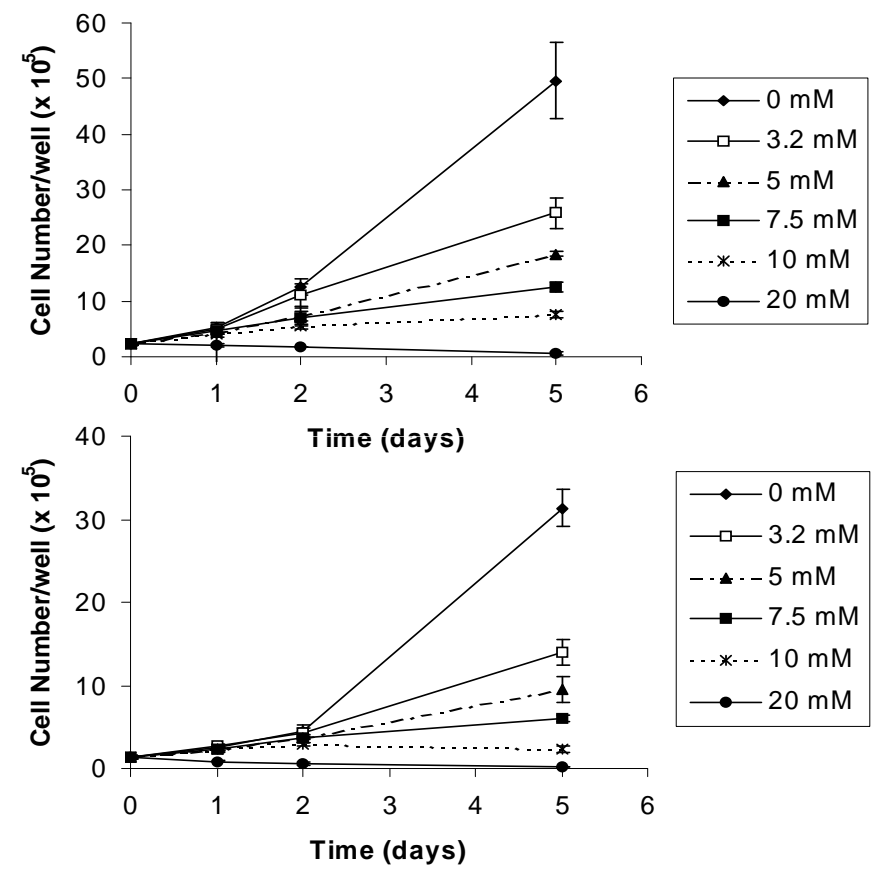

Fig.1. Inhibition of HT29 (top) and COLO 205 (bottom) cell growth by PEG. One day after seeding, exponentially growing cells were incubated with increasing concentrations of PEG from $3.2 \mathrm{mM}$ to $20 \mathrm{mM}$. At the indicated times, cellular growth was estimated by cell layer counting with a Coulter Counter. Values are the mean \pm SD of triplicate. When they do not appear, error bars are smaller than the symbol size.

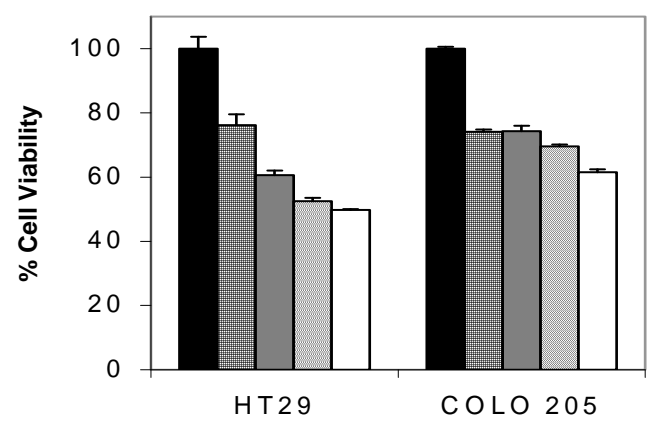

Fig.2. Effect of PEG on HT29 and COLO 205 cell viability. One day after seeding, exponentially growing cells were incubated with PEG (0mM (black bars), 3.2 $\mathrm{mM}$ (square grid), $5 \mathrm{mM}$ (grey), $7.5 \mathrm{mM}$ (hatched), 10 $\mathrm{mM}$ (white bars)). Cellular viability was estimated by MTT assay at day 2, as described in Material and Methods. Values are the mean \pm SD of triplicate

This antiproliferative effect was concentrationand time-dependent. The results show that PEG antiproliferative effect was significant at day two in HT29 cells (Fig.1.a), whereas it only affect significantly COLO 205 cell growth after 3 days of treatment (Fig.1.b). These results suggest that HT29 cells may be more sensitive to PEG than COLO 205 cells. Concomitantly, we examined the effect of PEG on HT29 and COLO 205 cell viability using MTT assay. Figure 2 shows a decrease in the cellular viability of PEG-treated cells compared to untreated cells. This effect was dose-dependent. However, we never observed dead cells floating in the supernatant.

PEG inhibited the reinitiation of DNA synthesis and blocked cells in $G_{0} / G_{1}$ of the cell cycle

We investigated the effect of PEG on FCS induced HT29 cell growth. Synchronized, quiescent HT 29 cells - obtained by serum deprivation during 18 hours- were then stimulated to grow by the addition of 5\% FCS, and incubated with increasing concentrations of PEG for 15 hours. Cell cycle response to PEG was then examined using flow cytometry analysis and results are shown in Fig.3. At time 0 , most cells were in $G_{0} / G_{1}$ phase due to the serum deprivation (Fig.3.a.A). Untreated cells showed the expected pattern for growth reinitiating cells (58\% of cells were in S phase, 15 hours after the addition of 5\% FCS) (Fig. 3.a.B). On the other hand, in the presence of 7.5 or $10 \mathrm{mM}$ PEG (Fig.3.a.D, E), we observed a strong inhibition of DNA synthesis. Cells were mainly in $G_{0} / G_{1}$ phase, only a few percent of cells entered in $S$ phase (5\%). Even, the low 3.2 mM PEG concentration inhibited significantly DNA synthesis reinitiation. We next examined the effect of PEG on non synchronized cells (Fig.3.b). When HT29 cells were incubated for 2 days with increasing concentrations of PEG, we observed a clear dose-response increase in the percent of cells in $G_{0} / G_{1}$ phase. This effect was dose-dependent and was correlated with a decrease in the percentage of cells in the $S$ phase of the cell cycle.

\section{Effect of PEG on cellular metabolism}

The effect of PEG on the major energyproviding pathway of cancerous cell, i.e. glycolysis, was estimated by measuring lactate release in the culture medium. As shown in Fig.4, addition of PEG in the culture medium of HT29 cells increased lactate release in the medium compared to untreated cells, 48 hours after the beginning of the experiment. This effect was seen even for the smaller concentration of 
PEG (3.2 mM) which did not affect, at this time, the dividing cell growth.

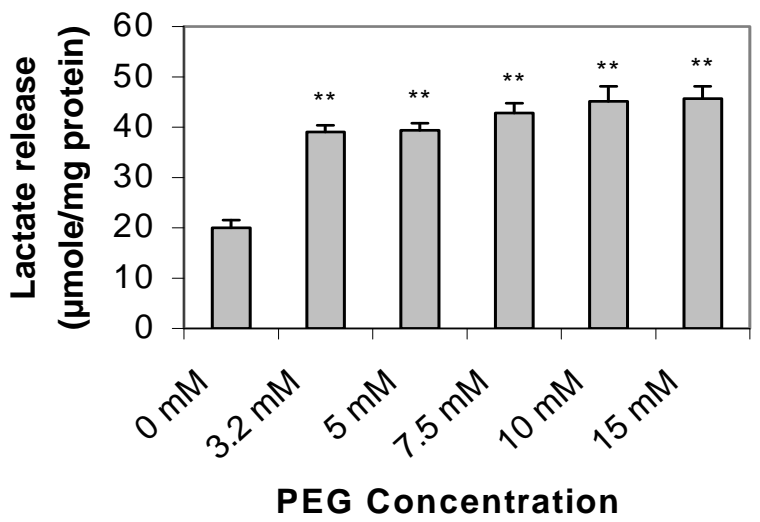

Fig.4. Effect of PEG on lactate release in HT29 cells. One day after seeding, exponentially growing cells were incubated with increasing concentrations of PEG for 48 hours. Lactate concentration of the culture medium was determined as described in Material and Methods. Values are the average of triplicate $\pm \mathrm{SD}$. ${ }^{* *} P<0.01$, significant difference compared with untreated cells ( 0 mM PEG).

\section{Structural changes induced by PEG}

We next investigated whether growth inhibition and glycolysis stimulation induced by PEG, may be linked with membrane and/or nuclei alterations. We analyzed the fluorescence of nuclei of cells stained with the DNA specific dye Hoechst 33342, and we observed cells using phase contrast microscope. Pictures were taken after 2 days of treatment (Fig.5). Fig.5.a shows, in phase contrast microscopy, typical morphology of untreated HT29 cells after two day of culture. As shown in fluorescence microscopy (Fig.5.c), they exhibited normal nuclei staining. By contrast as shown in Fig.5.d, PEG treated cells (5 mM) displayed condensed chromatin. As chromatin condensation is a characteristic of cells undergoing apoptosis, we next verified whether classical DNA ladder appeared in PEG treated cells. The DNA gel electrophoresis did not reveal DNA breaks pattern on HT29 cells treated with PEG (range from 3.2 to $10 \mathrm{mM}$ ) for up to 2 days (data not shown). We have then used propidium iodide, a DNA dye that is excluded from cells with a nonleaky plasma membrane. Propidium Iodide staining was not seen among treated cells, which excludes a necrotic effect of PEG (data not shown). On the other hand, plasma membrane changes were observed in 48 hours treated cells (Fig. 5.f). Indeed most treated cells presented membrane bebbling (Fig.5.f), not seen in untreated cells (Fig.5.c). However, staining with annexin revealed that PEG induced no change in the phospholipid bilayers (data not shown). The lack of annexin staining, and of DNA ladders on electrophoresis, suggests that morphological changes observed in PEG treated cells could not be linked to the induction of apoptosis.

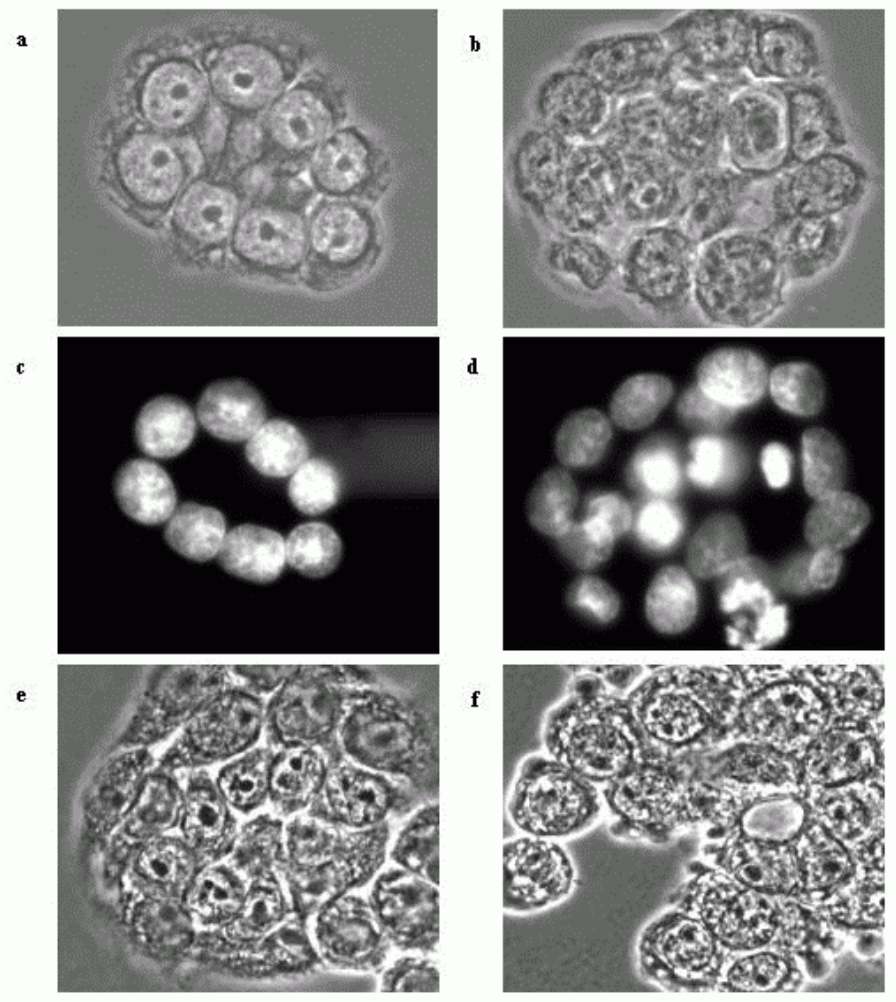

Fig.5. Structural changes induced by PEG in HT29 cells. One day after seeding, exponentially growing cells were treated with either 5 or $10 \mathrm{mM}$ PEG during 48 hours. At this time, cells were prepared and stained with Hoechst for fluorescence analysis as described in Material and Methods. a-b : phase contrast microscope analysis of untreated (a) and $5 \mathrm{mM}$ PEG treated cells (b). c-d : condensed nuclear chromatin in 5 mM PEG treated cells (d) compared with untreated cells (c) was demonstrated using Hoechst DNA staining as described in M.andM. e-f : phase contrast microscope analysis of cells showing membrane blebbing in $10 \mathrm{mM}$ PEG treated cells (f) compared with untreated cells (e). Bars: $5 \mu \mathrm{m}$.

\section{Effect of PEG on the culture medium osmotic pressure}

We have measured osmotic pressure of the culture medium after addition of PEG in the range of concentration from $3.2 \mathrm{mM}$ to $20 \mathrm{mM}$. Figure 6 clearly show that addition of PEG in the culture medium increased osmotic pressure in a dose-dependent manner. These results suggested that morphological changes observed in PEGtreated HT29 cells may be linked to the increase 
of osmotic pressure in the PEG-containing culture medium.

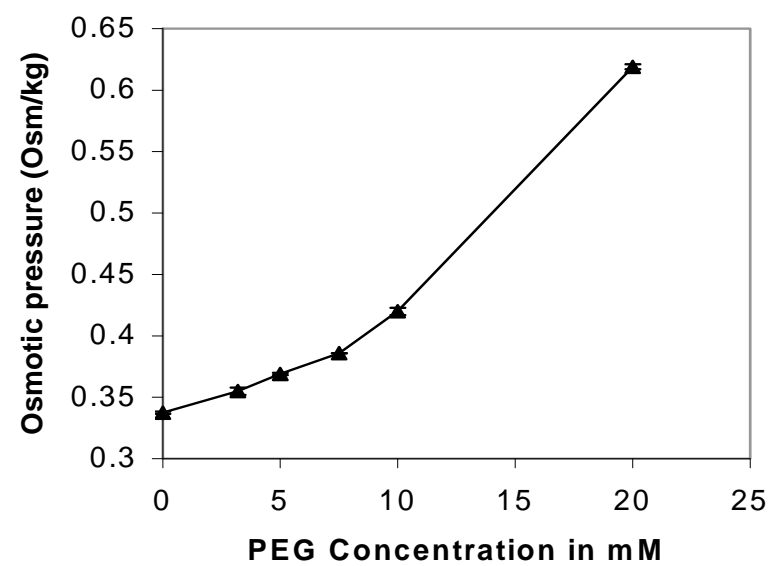

Fig. 6. PEG increased osmolarity of culture medium. At the beginning of the experiment a $100 \mu \mathrm{l}$ aliquot of the culture medium was analyzed for determination of osmotic pressure using an osmometer as described in Material and Methods. Values are the mean $\pm \mathrm{SD}$ of triplicate. When they do not appear, error bars are smaller than symbol size.

\section{Effect of hyperosmolarity on cell growth}

We next studied the effect of hyperosmolarity, obtained by addition of $\mathrm{NaCl}$ or sorbitol in the culture medium, on the proliferation rate and on the lactate production of HT29 cells. One day after seeding, the cell monolayers were incubated with $\mathrm{NaCl}(25 \mathrm{mM}$; $50 \mathrm{mM}$ or $150 \mathrm{mM}$ ) or with sorbitol $(50 \mathrm{mM}$; $105 \mathrm{mM}$ or $300 \mathrm{mM}$ ) for 48 hours. Figure 7 clearly show that growth of HT29 cells was inhibited as a function of increasing medium osmolarity. For example, a $0.45 \mathrm{Osm} / \mathrm{kg}$ medium obtained by addition of $105 \mathrm{mM}$ sorbitol or 50 $\mathrm{mM} \mathrm{NaCl}$ decrease cell number by respectively $53 \%$ and $26 \%$. It is noteworthy that $10 \mathrm{mM}$ PEG which increased osmolarity to $0.45 \mathrm{Osm} / \mathrm{kg}$ inhibited growth rate by 55\% (Fig 1 and 6). Moreover, lactate release by HT29 cells treated by either sorbitol or $\mathrm{NaCl}$ was dose-dependently increased compared to untreated cells.

\section{Effect of PEG on intestinal-like differentiated cells and on normal cells}

In order to check whether PEG exerted any toxic effect on normal cells, we next examined PEG effect on post-confluent intestinal-liked Caco-2 cells and on normal FHC cells. Colonic adenocarcinoma Caco-2 cells were allowed to grow for 2 weeks after they have reached confluence. At this stage, they have acquired an intestinal-like activity and phenotype
(Fogh and Zweibaum, 1983). Addition of various doses of PEG to post-confluent intestinal-like Caco-2 cells did not change their viability (Fig.8), or their function as estimated by phosphatase alcaline activity (not shown). Moreover in normal FHC cells, $5 \mathrm{mM}$ or $10 \mathrm{mM}$ PEG only decreased cell viability by $26 \%$ and $23 \%$ respectively (Fig.8), whereas in postconfluent HT 29 cells, which are still undifferentiated, $\mathrm{IC}_{50}$ of PEG was $8 \mathrm{mM}$ (not shown). These results suggested that PEG might have a selective effect on cancerous cells with less or no toxic effect on normal and on differentiated cells.

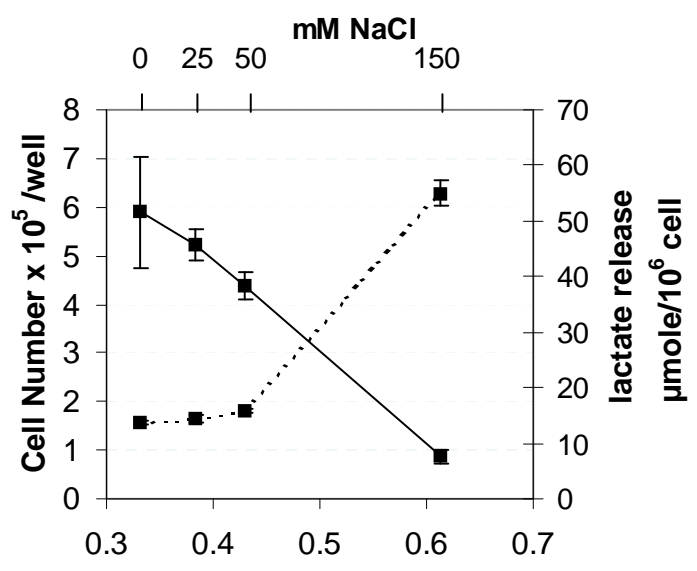

Osmotic pressure in Osmol/kg

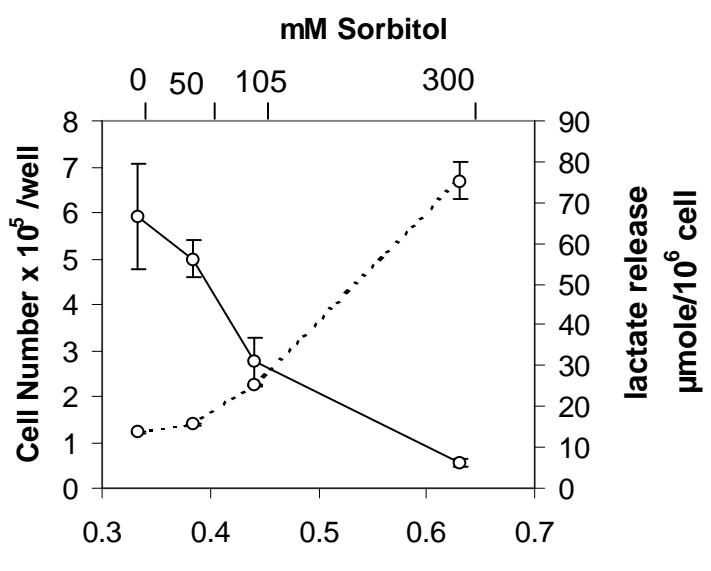

Osmotic pressure in Osmol/kg

Fig.7. Effect of hyperosmolarity on the growth and metabolism of HT29 cells. One day after seeding, cells were incubated with increasing concentrations of $\mathrm{NaCl}$ (top) or sorbitol (bottom) for 48 hours. At this time, cellular growth (full line) was estimated by cell layer counting with a Coulter Counter and lactate concentration of the culture medium (dotted line) was determined as described in Material and Methods. Values are the average of triplicate \pm SD. When they do not appear, error bars are smaller than the symbol size. 


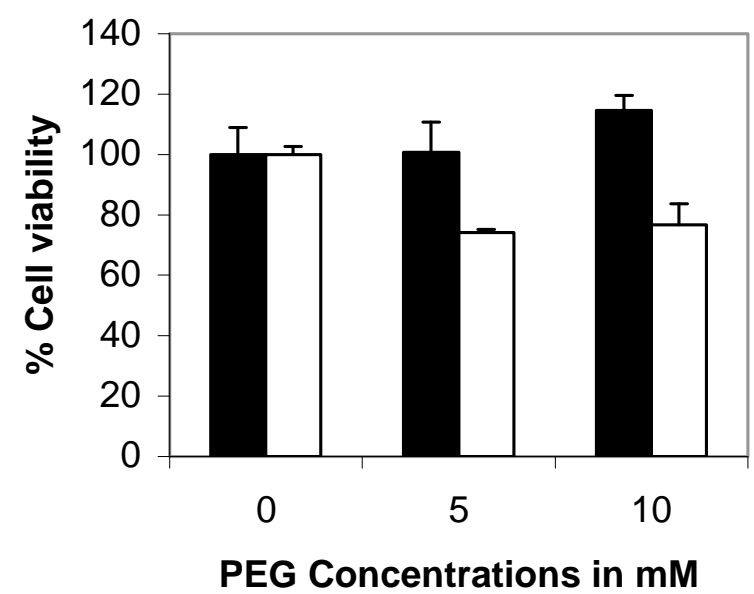

Fig.8. Effect of PEG on the viability of post-confluent intestinal-like CaCo-2 cells and normal FHC cells. Caco-2 cells (black ) were allowed to grow for 2 weeks after they have reached confluence and were then treated with $5 \mathrm{mM}$ or $10 \mathrm{mM}$ of PEG during 5 days. FHC cells (white $\square$ ) were grown to $80 \%$ confluence and were treated like Caco2 cells. Cell viability was estimated by MTT assay as described in Material and Methods. Values are the mean \pm SD of triplicate.

\section{DISCUSSION}

The results show that PEG inhibited proliferation of two human colonic adenocarcinoma cells. This effect was correlated with a blocking in the $G_{0} / G_{1}$ phase of the cell cycle. Moreover, PEG was not toxic on post-confluent intestinal-like $\mathrm{CaCo}-2$ cells and only slightly decreased normal FHC cell viability. The results also show that, in cancerous cells, PEG did not induce cell death, i.e. PEG only exerted a cytostatic effect. Indeed, the percent of cell viability in PEG-treated cells was not changed compared to the starting value. Moreover, floating cells in the culture medium were never observed in PEG-treated cells. Our results also show clearly that PEG did not induce characteristic features of programmed cell death, i.e., change in the phospholipid bilayer and DNA breakage.

Laboisse et al have shown that, a short exposure with $270 \mathrm{mM}$ PEG, elicited, 3 weeks later, the emergence of typical flat-foci in cultured HT29 cells, which were shown to differentiate into both enterocytic and mucus-secreting cells (Laboisse et al., 1988). We thus suggest that PEG-treated cells may undergo differentiation, since after 5 days of treatment, cells did not die and had stopped to grow.

PEG is a linear polymer made up of repeated twocarbon-length hydrocarbons joined by oxygen in an ether linkage. This allows for hydrogen bounding of the oxygen with surrounding water molecules. Addition of PEG in aqueous solution thus increases osmotic pressure of the solution by sequestering water (Schiller et al., 1988). Indeed, addition of $10 \mathrm{mM}$ PEG to the culture medium led to a $27 \%$ increase of the osmotic pressure (Fig. 6). Published studies show that an hyperosmotic shock leads to changes similar to those we have observed in PEG-treated HT29 cells. An osmotic shock induces major changes in nuclear chromatin organization of mammalian cells (Delpire et al., 1985). In a medium of high osmolarity, cells undergo an hypercondensation of the nuclear chromatin (Gilles et al., 1995), formation of cytoplasmic vesicles (Clegg et al., 1986), and many bleb-like structures (Gilles et al., 1995), often correlated with a reduced growth rate (Silvotti et al., 1991). Most cell types subjected to abrupt and large variations in environmental osmolarity show, after an initial phase of volume change, a volume regulation process. This phenomenon can be linked to the accumulation of small organic molecules such as polyols, oligosaccharides, and amino acids (Yancey et al., 1982). Transformed cells are more sensitive than their normal counterparts to hyperosmolarity (Silvotti et al., 1991). Indeed post-confluent intestinal-like CaCo-2 cells and normal FHC cells were, respectively, not or less affected by PEGincreased osmolarity than adenocarcinoma cells (HT29 and COLO 205). Transformed cells might have a defective modulation of ion fluxes and channels involved in the volume regulation. Moreover, the reduction of cell volume and of water content caused by hyperosmotic pressure can stimulate glycolysis and lactate release (Graf et al., 1988; Lang et al., 1989; Clegg et al., 1990). The increased glycolysis likely provides the extraenergy needed to regulate cell volume. We thus suggest that the growth inhibition, the structural changes, and the increased lactate release that we observed in PEG-treated HT29 cells might be due, at least in part, to the PEG-increased osmolarity of the medium. Indeed, at equiosmolarity, $105 \mathrm{mM}$ sorbitol exerted a similar antiproliferative effect than $10 \mathrm{mM}$ PEG (a 50\% growth inhibition) whereas $50 \mathrm{mM} \mathrm{NaCl}$ diminished proliferative activity only by $26 \%$, suggesting that other mechanisms could be taken in account. 
High molecular weight PEGs (4000 to 10000) are not absorbed from the gut in humans and in rats, and are excreted in stools (Winne et al., 1982; Schiller et al., 1997). A simple calculation shows that the fecal water in rats fed a 5\% PEG-diet contained approximately $30 \mathrm{mM}$ PEG (Corpet and Parnaud, 1999). Indeed, the osmolarity of fecal water was $0.5 \mathrm{Osm} / \mathrm{kg}$ in PEGfed rats, compared with $0.3 \mathrm{Osm} / \mathrm{kg}$ in control rats (unpublished observation). So, the range of PEG concentrations examined in this in vitro study can be achieved in vivo. Therefore, we propose that PEG could specifically inhibit the growth of azoxymethane-initiated proliferative cells, thanks to its osmotic properties. This specific cytostatic effect could lead to the inhibition of preneoplastic lesions, and may explain the prevention of colon cancer in rats (Parnaud et al., 1999).

\section{Dietary PEG strongly suppresses} azoxymethane-induced carcinogenesis in rats (Parnaud et al., 1999). This osmotic laxative does not belong to any previously recognized class of chemopreventive agents. PEG is roughly ten times more potent than any other agent on preneoplastic lesion end-point, and it is one of the most potent agents on cancer end-point. However, the cancerpreventive features of PEG should be confirmed in a human study.

\section{ACKNOWLEDGEMENTS}

This work was supported in part by the Direction Générale de l'Enseignement et de la Recherche du Ministère de l'Agriculture in France, and by the Institut National de la Recherche Agronomique in France. G. P. was supported by a grant from the ligue Nationale contre le Cancer, Gers, France. We thank Dr Georges Cassar (INSERM U395, Toulouse, France) for cytofluorimetry analysis of cell cycle.

\section{REFERENCES}

ALABASTER, O., TANG, Z.C., FROST, A. and SHIVAPURKAR, N., Potential synergism between wheat bran and psyllium - enhanced inhibition of colon cancer. Cancer Letters., 75, 53-58 (1993).

ATTAR, A., LEMANN, M., FERGUSON, A., HALPHEN, M., BOUTRON, M.C., et al., Comparison of a low dose polyethylene glycol electrolyte solution with lactulose for treatment of chronic constipation. Gut, 44, 226-230 (1999).

BRADFORD, M.M., A rapid sensitive technique for the quantification of protein utilizing the principle of proteindye binding. Anal. Biochem., 72, 248-254 (1976).

CLEGG, J.S., GALLO, J. and GORDON, E., Some structural, biochemical and biophysical characteristics of
L929 cells growing in the presence of hyperosmotic sorbitol concentrations. Exp. Cell Res., 163, 35-46 (1986). CLEGG, J.S., JACKSON, S.A. and FENDL, K., Effects of reduced cell volume and water content on glycolysis in L929 cells. J. Cell. Physiol., 142, 386-391 (1990).

CORPET, D.E. and PARNAUD G., Polyethylene-glycol, a potent suppressor of azoxymethane-induced colonic aberrant crypt foci in rats. Carcinogenesis, 20, 915-918 (1999).

CORPET, D.E., PARNAUD, G., DELVERDIER, M., PEIFFER, G., and TACHE, S., Consistent and fast inhibition of colon carcinogenesis by PEG in mice and rats given various carcinogens. Cancer Res., 60, 3160-3164 (2000).

DELPIRE, E., DUCHÊNE，C., GOESSENS, G. and GILLES, R., Effects of osmotic shocks on the ultrastructure of different tissues and cell types. Exp. Cell Res., 160, 106-116 (1985).

FOGH, J., ZWEIBAUM, A. Enterocitic-like differentiation and polarization of the human colon carcinoma cell line Caco-2 in culture. Biol. Cell, 47, 323330 (1983).

GILLES, R., BELKHIR, M., COMPERE, P., LIBIOULLE, C. and THIRY, M., Effect of high osmolarity acclimation on tolerance to hyperosmotic shocks in L929 cultured cells. Tissue and Cell, 27, 679687 (1995).

GRAF, J., HADDAD, P., HAEUSSINGER, D. and LANG, F., Cell volume regulation in liver. Ren. Physiol. Biochem., 11, 202-220 (1988).

HOHORST, H. and BERGMEYER, H.U., L-lactate determination. In : H.U., BERGMEYER (ed), Methods of enzymatic analysis, pp. 622-637, Verlag Chemie, Weinheim, (1974).

HUSOY, T., SYVERSON, T. and JENSSEN, J., Comparison of four in vitro cytotoxicity tests: the MTT assay, NR assay, uridine incorporation and protein measurements. Toxicol. In Vitro, 7, 149-154 (1993).

LABOISSE, C.L., MAORET, J.J., TRIADOU, N. and AUGERON, C., Restoration by polyethylene glycol of characteristics of intestinal differentiation in subpopulations of the human colonic adenocarcinoma cell line HT29. Cancer Res., 48, 2498-2504 (1988).

LANG, F., STEHLE, T. and HAUSSINGER, D., Water, $\mathrm{K}+, \mathrm{H}+$, lactate and glucose fluxes during cell volume regulation in perfused rat liver. Pflugers Arch., 413, 209216 (1989).

PARNAUD, G., TACHE, S., PEIFFER, G. and CORPET D.E., Polyethylene-glycol suppresses colon cancer and causes dose-dependent regression of azoxymethaneinduced aberrant crypt foci in rats. Cancer Res., 59, 51435147 (1999).

POTTER, J.D., Colon cancer - do the nutritional epidemiology, the gut physiology and the molecular biology tell the same story. J. Nutr., 123, 418-423 (1993).

SCHILLER, L.R., EMMETT, M., SANTA ANA, C.A. and FORDTRAN J.S., Osmotic effects of polyethylene glycol. Gastroenterology, 94, 933-941 (1988)

SCHILLER, L.R., SANTA ANA, C.A., PORTER, J. and FORDTRAN J.S., Validation of polyethylene glycol 3350 as a poorly absorbable marker for intestinal perfusion studies. Dig. Dis. and Sci., 42, 1-5 (1997) 
SILVOTTI, L., PETRONINI, P.G., MAZZINI, A., PIEDIMONTE, G. and BORGHETTI, A., F., Differential adaptative response to hyperosmolarity of 3T3 and transformed SV3T3 cells. Exp. Cell Res., 193, 253-261 (1991).

STAVRIC, B., Role of chemopreventers in human diet. Clin Biochem, 27, 319-332 (1994).

VINDELOV, L.C. and CHRISTENSEN, I.J., A review of techniques and results obtained in one laboratory by an integrated system of methods designed for routine clinical flow cytometric DNA analysis. Cytometry, 11, 753-770 (1990).
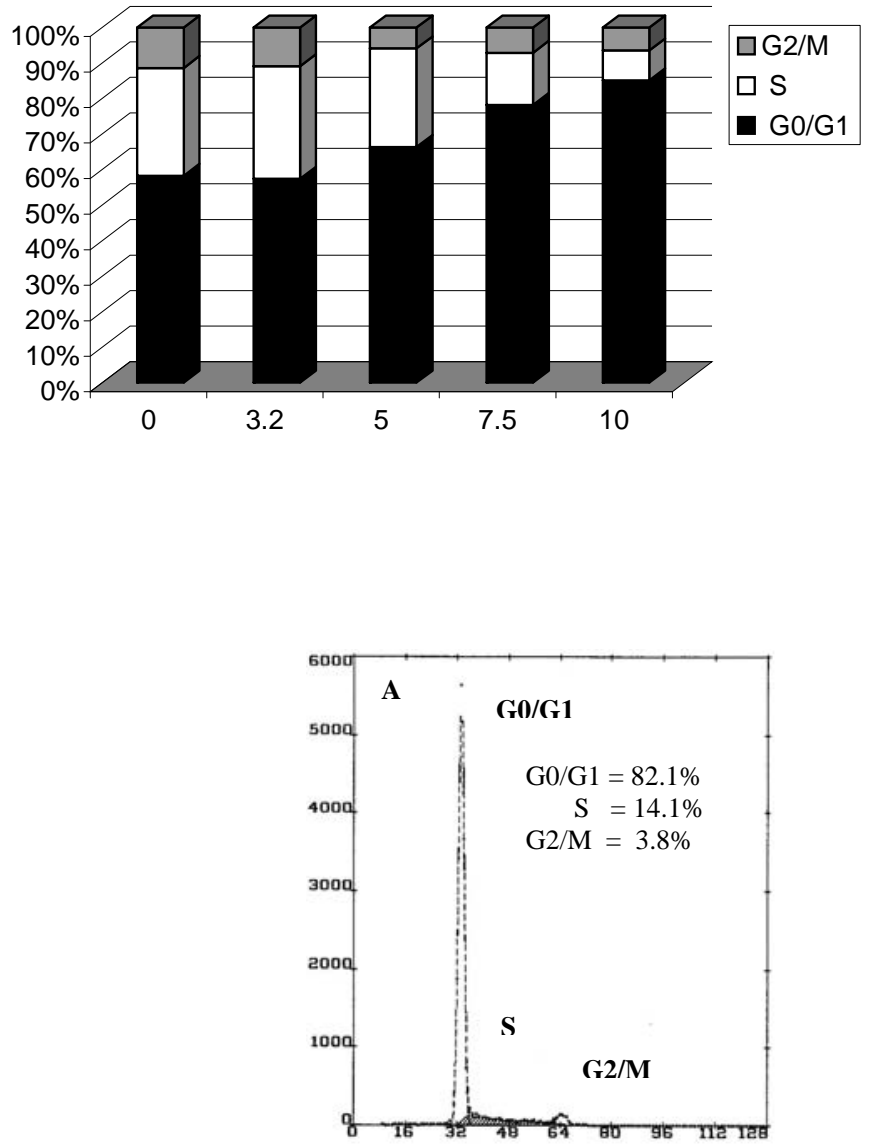

WEISS, H.A. and FORMAN, D., Aspirin, non-steroidal anti-inflammatory drugs and protection from colorectal cancer: a review of the epidemiological evidence. Scandin. J. Gastroenterology, 31, 137-141 (1996).

WINDHOLZ, M., (ed). The Merck Index, $10^{\text {th }}$ edn. Rathway, NJ (1983).

WINNE, D. and GORIG, H., Appearance of 14Cpolyethylene glycol 4000 in intestinal venous blood: influence of osmolarity and laxatives, effect on net water flux determination. Naunyn Schmiedebergs Arch. Pharmacol., 321, 149-156 (1982).

YANCEY, P.H., CLARK, M.E., HAND, S.C., BOWLUS, R.D. and SOMERO, G.N., Living with water stress: evolution of osmolyte systems. Science, 217, 1214-1222 (1982).

Fig.3. Effect of PEG on HT29 cell cycle.

bottom: synchronized and quiescent HT 29 cells obtained by serum deprivation during 18 hours- were then stimulated to grow by the addition of 5\% FCS alone (B), and in the presence of 3.2 (C), 7.5 (D) or 10 (E) mM PEG for 15 hours. Quiescent cells were also maintained in serum free medium during 15 hours (A). Cell cycle was analyzed by flow cytometry as described in Material and Methods.

left: one day after seeding, cells were incubated with increasing concentrations of PEG for 48 hours and then analyzed for cell cycle. Results are the mean of one typical experiment. Each point was done in triplicate.

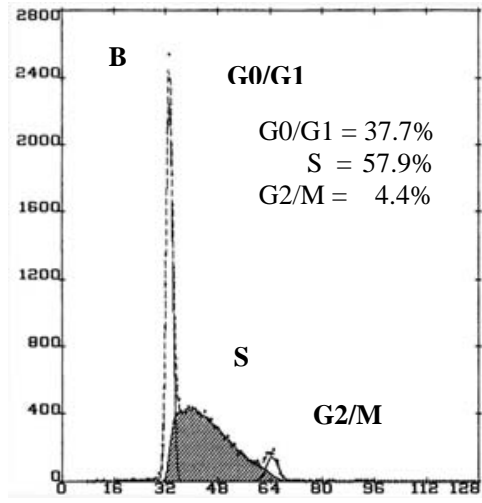

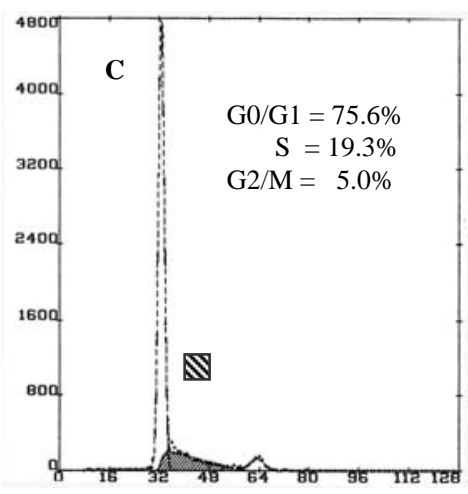
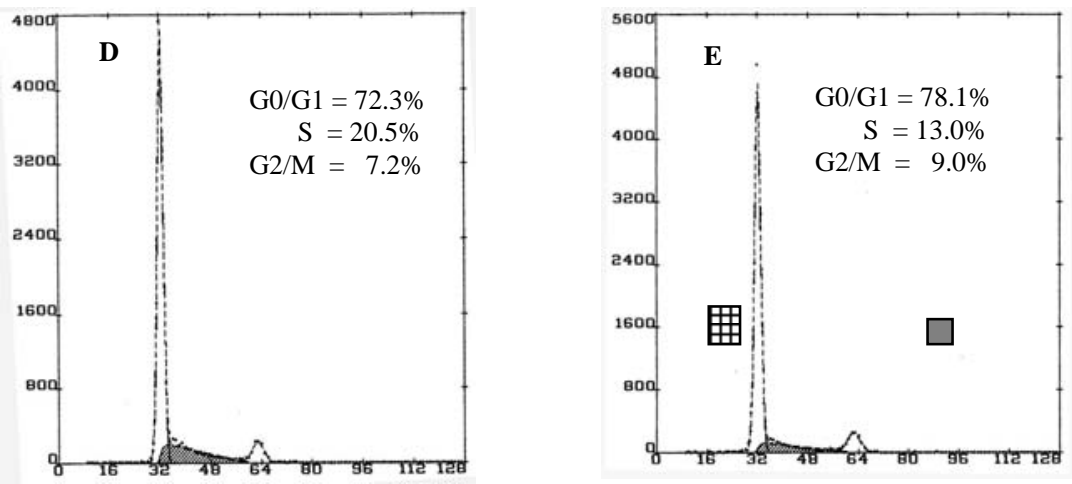